\title{
Variation in protein content of peas under Finnish conditions
}

\author{
REIJO KARJALAINEN
}

Department of Plant Breeding, University of Helsinki, SF-00710 Helsinki 71, Finland

\author{
SIMO HOVINEN
}

\section{Hankkija Plant Breeding Institute, SF-04300 Hyrylä, Finland}

\begin{abstract}
The variation of protein content and correlations between protein content and agronomic traits were studied on materials in variety trials over five years and at two locations in southern Finland.

Protein content and protein yield of a given genotype varied widely in different years. High temperature during the growing season was the main climate factor influencing protein content. Statistically significant variation in protein content was found between different genotypes.

Correlations between protein content and seed yield were weak, negatively significant in only two years. The relationship between seed weight and protein content was negative in all years. Late maturity was positively associated with protein content in all years and at both locations. It is suggested that breeding for protein productivity in northern conditions it is more effective to improve seed yield and yield stability than to attempt improving protein content.
\end{abstract}

\section{Introduction}

Leguminous plants play an increasingly important role in modern agriculture. In the search for a crop plant yielding a high level of seed protein at a low energy cost, such traits as the ability to fix nitrogen biologically and to yield abundant protein simultaneously are of crucial importance to countries like Finland, because their agricultural production is based on imported energy (see e.g. VARIS 1981).

Peas are the most important grain legumes in Finland. The cultivation of peas for fodder and cooking is beset by various climatic problems, and annual variations in cultivation area and average yield are considerable (HOVINEN and KARJALAINEN 1981). The main goal behind our breeding programs is to improve cultivation stability by improving earliness, seed yield, and resistance to lodging and diseases, which are decisive characters under northern growing conditions (KIVI 1978, 1979).

The variation of protein content in peas is wide, and it is affected by genetic and environmental factors such as soil fertility, fertilization, water sypply, microclimate, alterations of weather conditions, macroclimatic conditions, and latitude (ALI- 
KHAN and YOUNGS 1973, GOTTSCHALK 1978). Moreover ALI-KHAN (1977) has found that protein content is dependent on sowing time.

PESOLA (1955), a Finnish pea breeder, was one of the first authors to suggest that the protein content of peas was genetically determined. Heritability values in different studies vary depending e.g. on parent material, experimental design and methods of calculation. PANDEY and GRITTON (1976) used the parent-offspring regression method analysed on four pea crosses, and obtained heritability values ranging from $17 \%$ to $56 \%$. The highest value was detected in the cross with the widest range in protein content. In a recent Polish study, (SCWIECICKI et al. 1980 ) heritability values in two crosses were $29.2 \%$ and $70.4 \%$. In a cross between high and medium protein varieties, dominance was much greater than in a cross between cultivars with low and medium protein contents. According to these results, it would be easier to obtain the desired results by making crosses involving varieties with medium protein content.

In recent years, the negative association between protein content and grain yield has been one of the major difficulties in cereal protein breeding. The synthesis of storage proteins requires a relatively large amount of metabolic energy for which the synthesis of carbohydrates competes (RABSON et al. 1978). Thus it is not sufficient simply to incorporate into the genotype factors which act to increase the amount of storage protein in the seed. They must be combined with genes which improve the efficiency of the plant in synthesising proteins (EVANS and DAVIES 1980).

Negative correlations between protein content and seed yield in peas have been reported by many authors (e.g. JERMYN and SLINKARD 1977, BINGEFORS et al. 1979, BLIXT 1979). Positive correlations have also been reported (ALI-KHAN and YOUNGS 1973, PANDEY and GRITTON 1976).

In many cases the improvement of protein content seems to be difficult in variable northern conditions, because protein content is srongly affected by climatic factors. In his review of the achievements of recent pea breeding, SNOAD (1980) states that there is information, genetic variation and agronomic input available for improving grain yield, but that nothing comparable is available for improving the protein content of the seed.

The present paper is a report on genotypic and environmental variation of protein content and on correlations between protein content and agronomic traits. Moreover, an attempt is made to define the main climatic factors influencing protein contents.

\section{Materials and methods}

Variations in protein content and their relations to other characteristics were examined from the results of standard variety trials carried out by the Hankkija Plant Breeding Institute. The results were collected over the period 1975-1980, and at two locations, Anttila $\left(60.42^{\circ} \mathrm{N}\right)$ and Nikkilä $\left(61.55^{\circ} \mathrm{N}\right)$ Experimental Farms. The trials were sown on mineral soils with a high clay content. The level of nitrogen fertilization varied from 16 to $48 \mathrm{~kg} \mathrm{~N} / \mathrm{ha}$. Because of extremely cool seasons, the trials failed at Nikkilä in 1976, and at both localities in 1977 (see Fig. 1). 

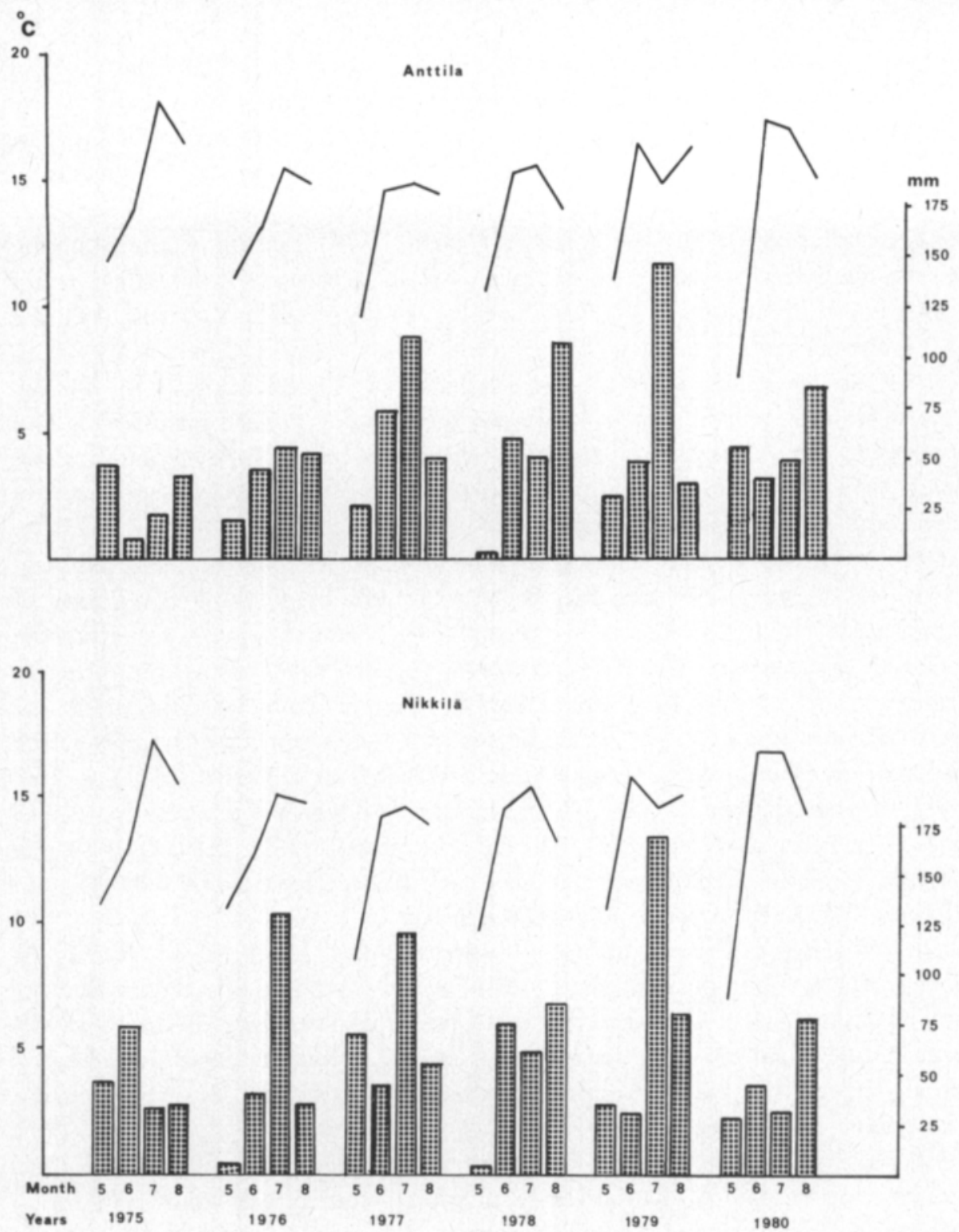

Fig. 1. Monthly averages of temperatures $\left({ }^{\circ} \mathrm{C}\right)$ from 1975 to 1980 and monthly precipitation (mm) between May and August at the Experimental Farms of Anttila and Nikkilä.

The effects of climatic factors on the protein content of the Dutch variety Rondo were investigated by a stepwise multiple linear regression analysis. The protein percentages of Rondo were collected from 42 official trials carried out between 1969 and 1980 in the southern part of Finland. The variables considered were mean temperatures and precipitation for June, July and August. In addition, cloudiness and relative humidity percentages in August and latitude of trial locality were also taken into account. The $\mathrm{F}$ level for variable removal was 2.5 .

Statistical calculations of coefficients of variation, correlations and regressions were computed by standard procedures. 


\section{Results}

\subsection{Variation of protein content}

The annual variation in protein content of five genotypes is presented in Table 1. The coefficient of variation (in protein content) ranges from 4.31 to 9.12 .

The coefficients of variation of protein yield and seed yield are much higher than that of the protein content, which indicates that protein yield and seed yield are very sensitive in their reactions to variable climatic conditions. The fairly similar values for variation of protein yield and seed yield indicated that under Finnish conditions protein productivity depends much more on seed yield than on protein content.

Significant variation in protein content was detected between different cultivars and lines grown in variety trials (Table 2). The range of protein content is $23.1 \%$

Table 1. Means, standard deviations and coefficients of variation of protein content, protein yield and seed yield of five genotypes grown at Anttila and Nikkilä in 1975-1980. Varieties in increasing order of earliness.

\begin{tabular}{|c|c|c|c|c|c|c|c|c|c|}
\hline \multirow[t]{2}{*}{ Variety } & \multicolumn{3}{|c|}{ Protein \% } & \multicolumn{3}{|c|}{ Protein yield $\mathrm{kg} / \mathrm{ha}$} & \multicolumn{3}{|c|}{ Seed yield $\mathrm{kg} / \mathrm{ha}$} \\
\hline & $\mathrm{x}$ & S.D & C.V & $\bar{x}$ & S.D & C.V & $\bar{x}$ & S.D & C.V \\
\hline Simo & 25.78 & 1.64 & 6.36 & 923.91 & 490.71 & 53.11 & 3598.18 & 1906.49 & 52.98 \\
\hline Jo 9161 & 24.37 & 1.14 & 4.67 & 926.30 & 404.26 & 43.64 & 3814.00 & 1889.96 & 44.31 \\
\hline Kiri & 26.50 & 1.81 & 6.85 & 854.36 & 375.69 & 43.97 & 3252.73 & 1481.48 & 45.54 \\
\hline $\mathrm{Hja}$ 's & & & & & & & & & \\
\hline Hemmo & 26.22 & 2.39 & 9.12 & 973.36 & 405.13 & 41.62 & 3774.54 & 1647.94 & 43.66 \\
\hline Rondo & 23.45 & 1.01 & 4.31 & 818.64 & 350.54 & 42.79 & 3486.36 & 1480.62 & 42.47 \\
\hline
\end{tabular}

Table 2. Protein content and protein yield of cultivars and breeding lines of peas grown on the trials at the Hankkija Plant Breeding Institute, Experimental farms of Anttila and Nikkilä

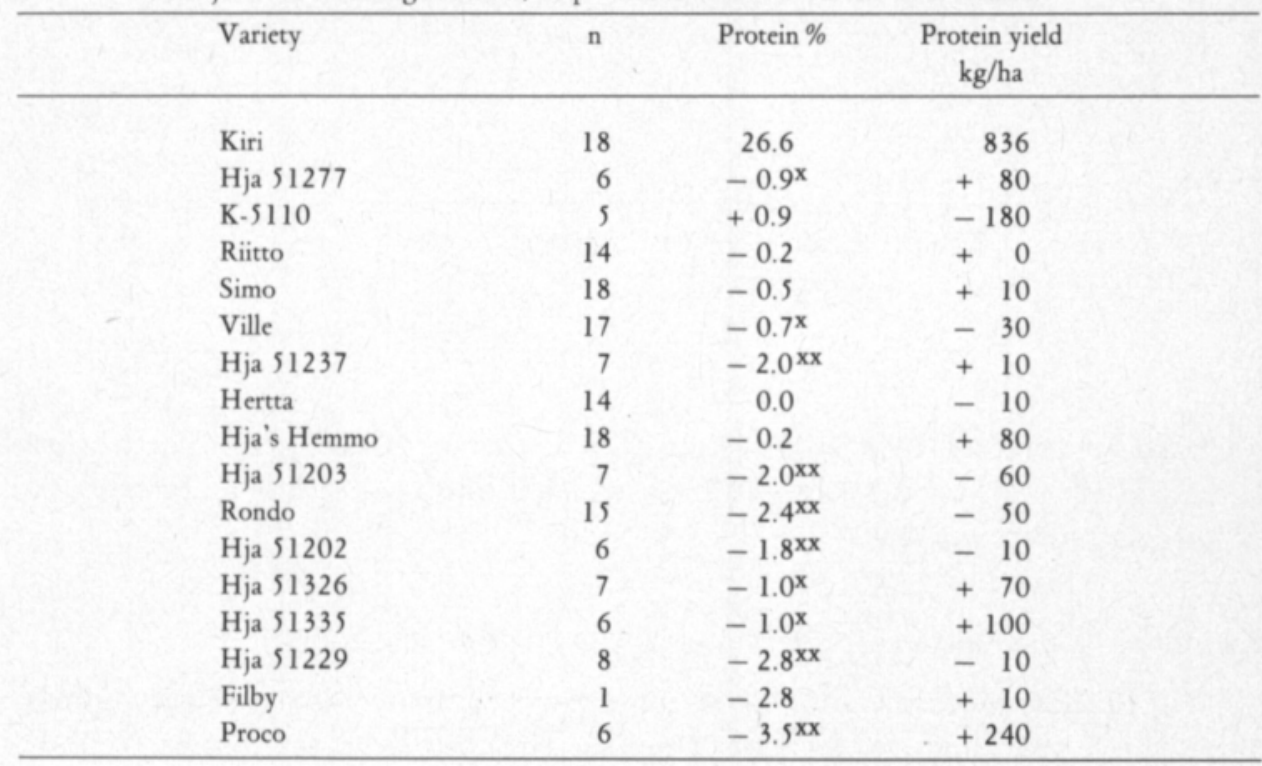



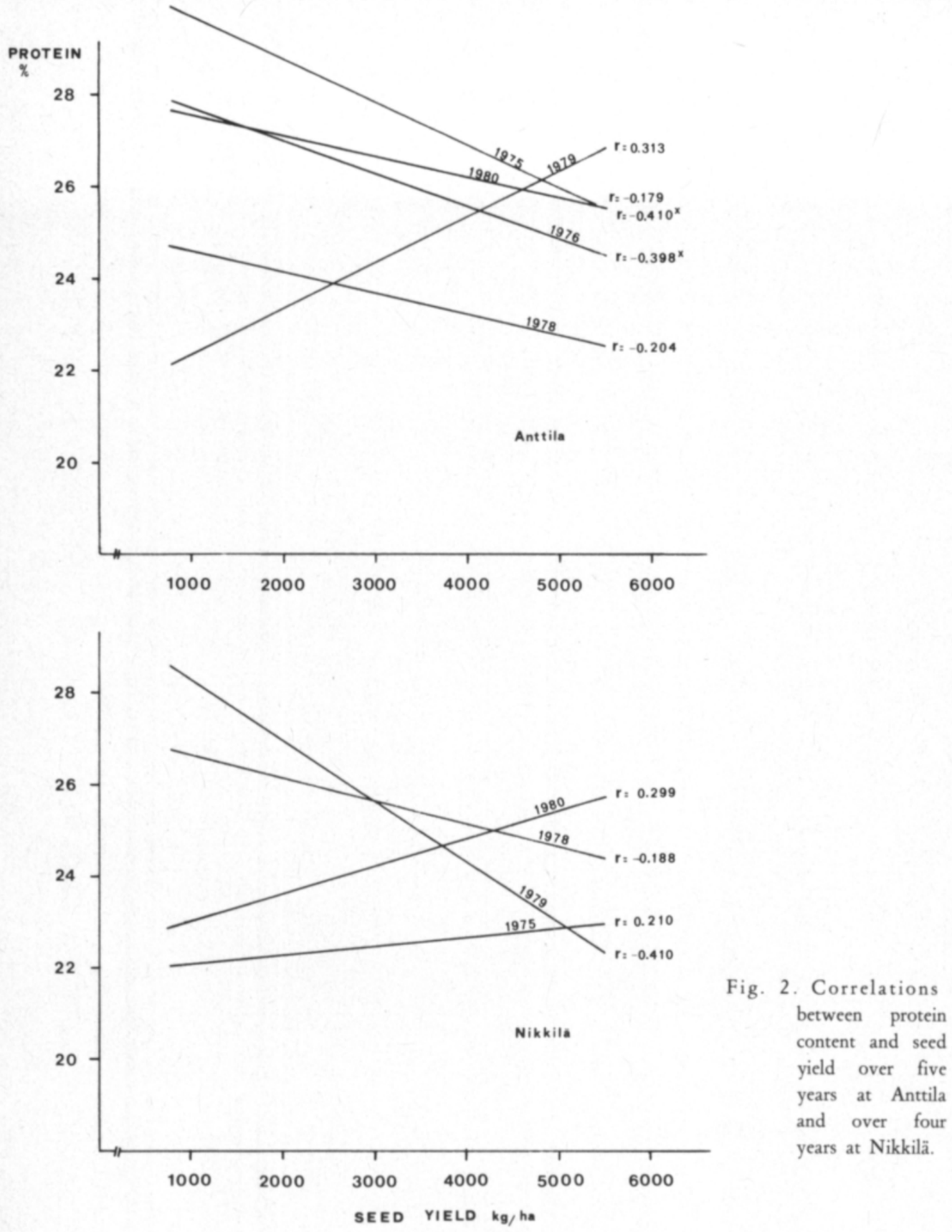

$27.5 \%$. The protein yield ranges from $650 \mathrm{~kg} / \mathrm{ha}$ to $1070 \mathrm{~kg} / \mathrm{ha}$. The highest figure was obtained for the cultivar Proco, which is borth the earliest and the lowest as regards protein content.

\subsection{Correlations between protein content and agronomic traits}

The phenotypic correlations between protein content and seed yield vary widely over the five years and two locations (Fig. 2). The coefficients were generally low. 


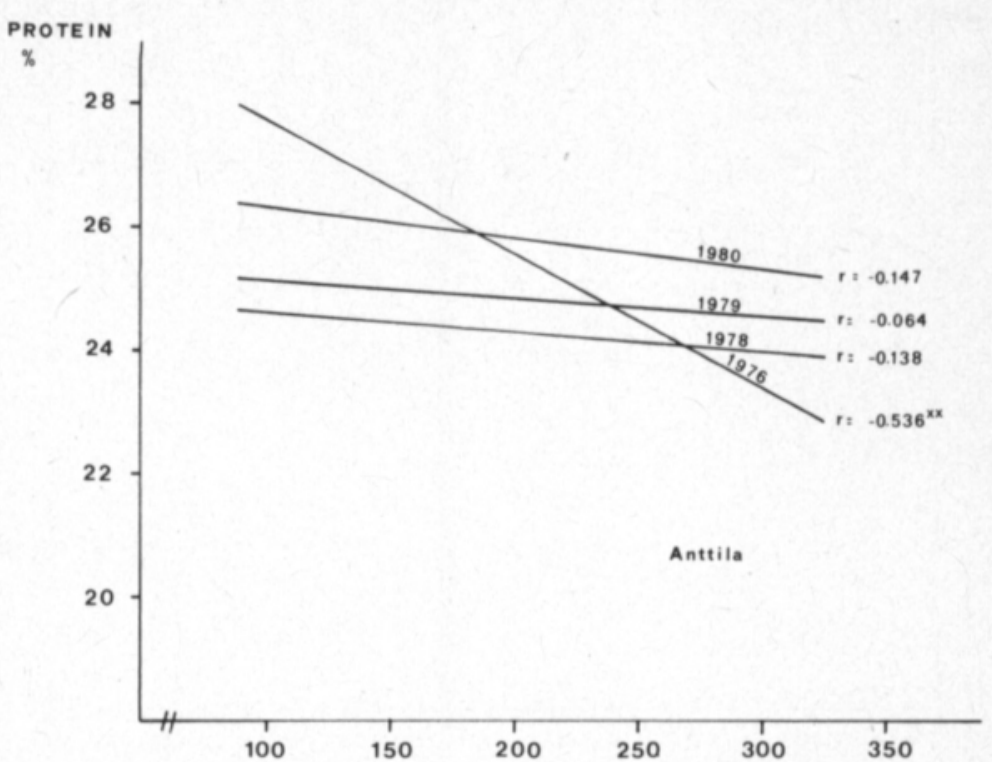

Fig. 3. Correlations between protein content and seed weight over four years at Anttila and Nikkilä.

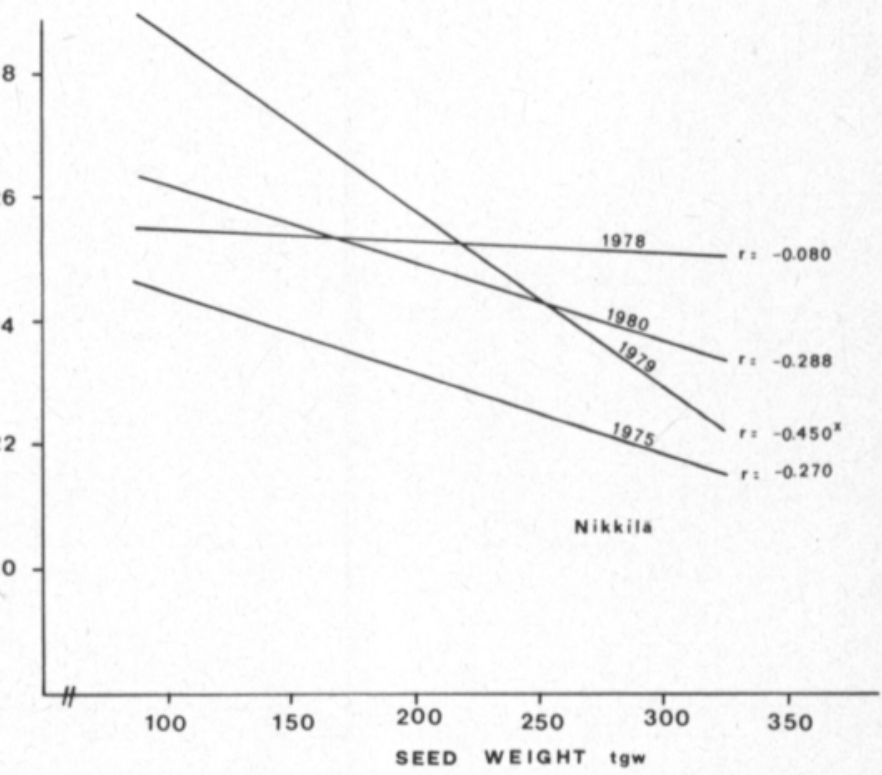

The relationship between protein content and seed weight is presented in Figure 3. In each year and at both locations the correlation is negative but weak.

Late maturity seems to be associated with high protein content (Fig. 4). Every coefficient of correlation is positive. At Anttila two coefficients were highly significant, and one significant.

A highly significant positive correlation was found between plant height and protein content indicating that it would be difficult to improve the protein content of low-stemmed varieties (Fig. 5). 

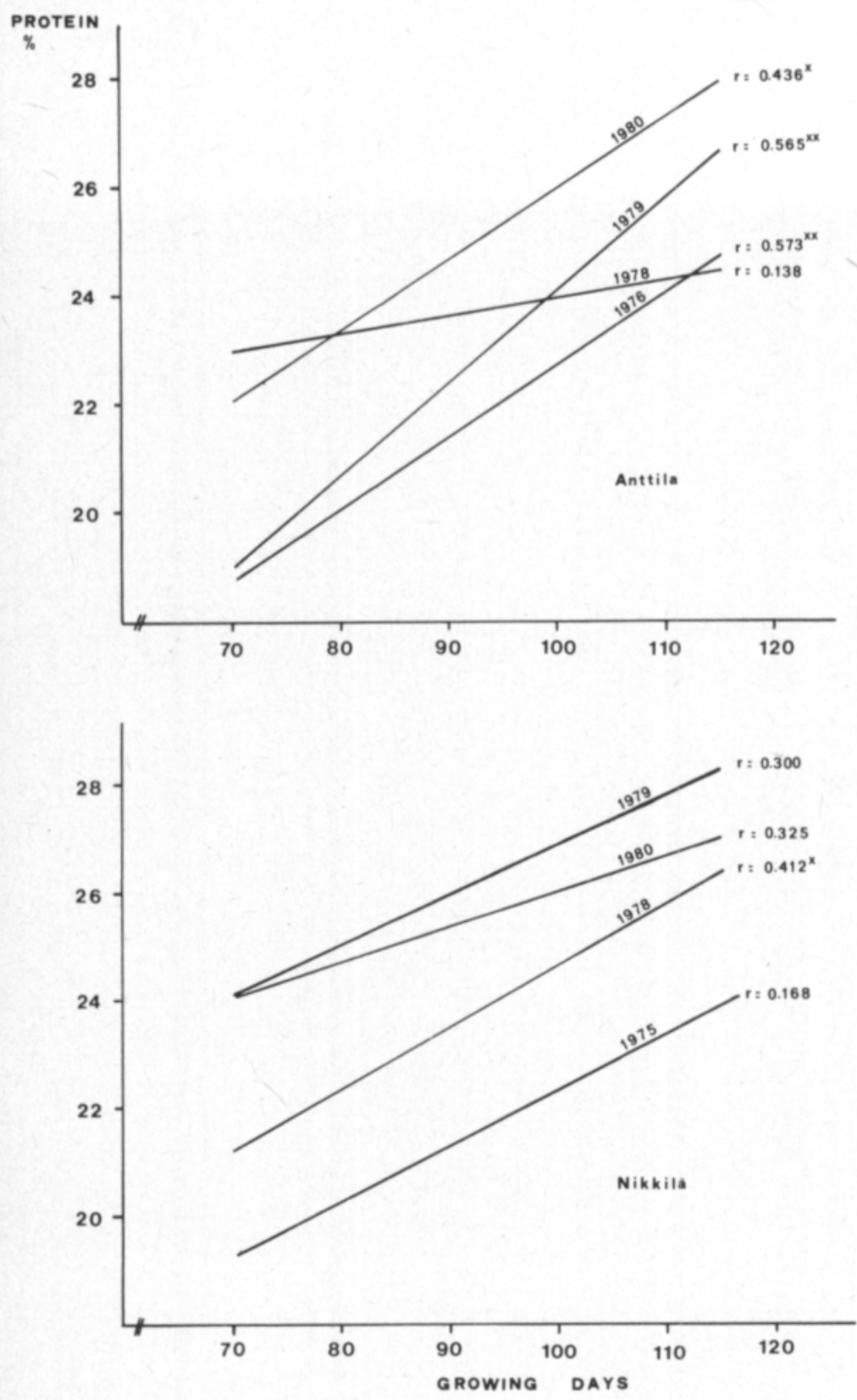

Fig. 4. Correlations between protein content and growing time over four years at Anttila and Nikkilä.

\subsection{Effects of climatic factors on protein content}

Only three climatic factors were incorporated into the regression modell, the mean July tempereture $\left(\mathrm{X}_{1}\right)$, June precipitation $\left(\mathrm{X}_{2}\right)$, and August cloudiness percentage $\left(\mathrm{X}_{3}\right)$. The regression equation $\mathrm{Y}=9.628+0.52460 \mathrm{X}_{1}+$ $0.03673 \mathrm{X}_{2}+0.05445 \mathrm{X}_{3}$ accounted for $32.3 \%$ ( $\mathrm{F}$ value $\left.6.048 \mathrm{xx}\right)$ of the variation in protein.

The correlation coefficients between climatic factors and protein content are presented in Table 3. 


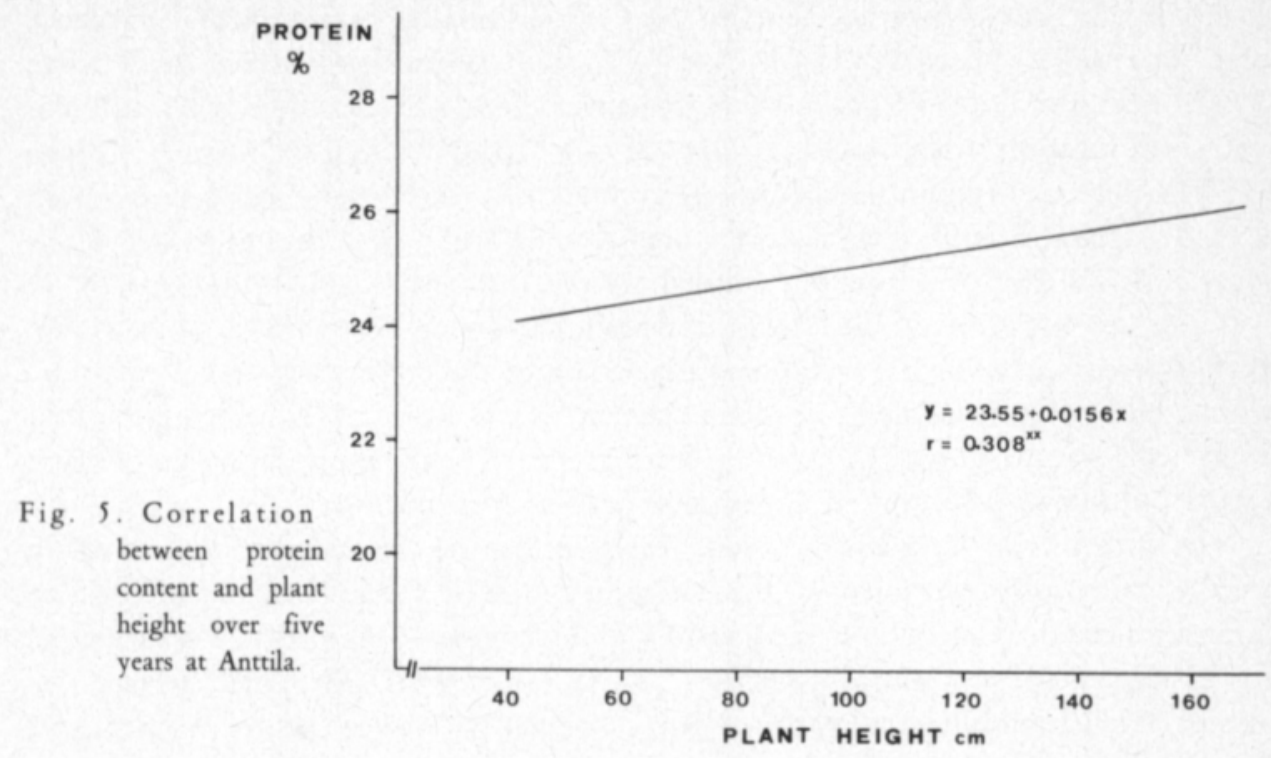

Table 3. Correlation coefficients between protein content of Rondo pea and some climatic factors.

\begin{tabular}{|c|c|c|}
\hline & Factors & Protein content \\
\hline & Mean temperature in June & 0.229 \\
\hline & $" \quad$ July & $0.411^{x x}$ \\
\hline & " August & 0.008 \\
\hline & Precipitation in June & 0.249 \\
\hline & " July & -0.254 \\
\hline & " August & 0.054 \\
\hline & Cloudiness in August & 0.293 \\
\hline & Relative humidity in August & -0.133 \\
\hline & Latitude & 0.020 \\
\hline
\end{tabular}

\section{Discussion}

One of the best ways of meeting the demand for domestic protein production in Finland is to cultivate peas. Peas contain abundant protein with a high biological value for animal feeding, and provides good raw material for fodder mixtures with barley and oats (HOLT and SOSULSKI 1979). Unfortunately the cultivation of peas in Finland has hitherto been limited because the present varieties are sensitive to climatic factors. Therefore, overall amount of protein obtained from peas has been small and foreign protein products, mainly soya-meal, have had an economic advantage over peas.

Investigations of the world collection reveal large variability in protein content of peas, ranging from 14 to $39 \%$, and almost as wide variation has been detected in Pisum mutants (GOTTSCHALK et al. 1975, BLIXT 1979).

The present results indicated that in Finland the variation in protein centent between genotypes is statistically significant, but large environmental effects 
occured, too. Early cultivars seem to be less sensitive to environmental influence than late ones, probably because of our short growing season. In Sweden BINGEFORS et al. (1979) found that protein content was less affected by different years and locations than by variety. On the other hand, ALI-KHAN and YOUNGS (1973) detected large annual and locational differences between genotypes in Canada. Under Finnish conditions the annual variation in protein content may be as wide as 20.6-29.8\% within one cultivar (HOVINEN and KARJALAINEN 1981).

Our investigations of the effects of climatic factors on protein content in Rondo peas showed fairly weak correlations. According to the present regression equation, about third of the variation in protein content was accountable by climatic factors. High temperature during the growing season seem to be the most important climatic factor influencing the protein content of peas in Finland.

In view of the variation in protein yields, it can be concluded that the protein yield is principally explained by the variability of seed yield. It would be ideal to improve protein content and seed yield simultaneously. Some successful attempts have been made on grain legumes (EVANS and GRIDLEY 1979), but this approach has been hindered by the negative association between protein content and seed yield.

The present results confirm previous ones indicating that protein content and seed yield are negatively correlated. They are fairly similar to those of BINGEFORS et al. (1979), and show that correlations vary between years and locations. Correlations were negative, but generally rather weak.

With regard to the relationship between seed weight and protein content, our results are similar to those of BINGEFORS et al. (1979) and indicate that seed weight is negatively associated with protein content, though generally the correlations seem to be low. In their studies on Pisum mutants GOTTSCHALK et al. (1975) found no association between seed weight and protein content.

Late maturity appears to be positively correlated with protein content. This relationship is weaker in the more northern locality at Nikkilä than at Anttila. Under Finnish conditions, late cultivars tend to produce lower yields than early ones, because only a small part of their seed reaches maturity. Plant height shows statistically significant positive correlation with protein content. In this material early cultivars seem to be short in comparison with late ones, thus confirming the relationship between protein and development.

Under Finnish conditions, peas can take the best possible advantage of biological nitrogen fixation. It is unprofitable to replace it by artificial nitrogen in fodder pea production. However, small amounts of nitrogen, $20-50 \mathrm{~kg} \mathrm{~N} /$ ha have given good results, because low levels of nitrogen do not destroy the balance of biological nitrogen fixation. In practical pea cultivation, it is to farmer's advantage arrange favourable environmental conditions for nitrogen fixation, thus enabling him to utilize the genetic resources of the variety in question for the highest protein content.

In the light of the present results some general conclusions may be drawn regarding protein improvement in peas. Under northern conditions the influence of environmental factors on protein production in peas is very great indeed. Protein yield and seed yield are closely associated and thus one might postulate that protein productivity depends much more on seed yield than on protein content. If this conclusion is generally applicable breeding efforts in Finland should be devoted to 
improving seed yield and yield stability. Our studies support the recent results published in Britain (SNOAD 1980) that it is four to five times more effective to improve seed yield than the protein content in breeding for protein productivity in peas.

Acknowledgements. We are grateful to Professors Erkki Kivi and Peter Tigerstedt for critical reading of the manuscript. We wish to thank Mr. Lassi Kontula for his computer support. The English text was kindly revised by Mr. Peter Joy and Mrs. Sinikka Karjalainen. The work was supported by the Ministry for Agriculture and Forestry (to University of Helsinki) which is gratefully acknowledged.

\section{References}

ALI-KHAN, S. T. 1977. Seed yield, seed weight, percent protein and protein yield of field peas as affected by seeding dates. Can. J. Plant Sci. 57: 17-20.

- \& YOUNGS, C. G. 1973. Variation of protein content in field peas. Can. J. Plant Sci. 53: 37-41.

BINGEFORS, S., QUITTENBAUM, G. \& TAPIA-ROJAS, J. 1979. Proteinhaltsvariationer i ärter. Sver. Utsädesför. Tidskr. 89: 189-208.

BLIXT, S. 1979. Natural and induced variability for seed protein in temperate legumes. In Seed protein improvement in cereals and grain legumes. (Proc. Meet. Neuherberg, 1978), IAEA, Vienna (1979) II, p. $3-20$.

EVANS, A. M. \& DAVIES, J. H. C. 1980. Breeding Phaseolus beans as grain legumes for Britain. Appl. Biol. 3: $1-37$.

- \& CRIDLEY, H. E. 1979. Prospect for the improvement of protein and yield in grain legumes. Curr. Adv. Plant Sci. 32: 1-17.

GOTTSCHALK, W., MÜLLER, H. P. \& WOLF, G. 1975. Relations between protein production, protein quality and environmental factors in Pisum mutants. In Breeding for seed protein improvement using nuclear techniques. (Proc. Meet. Ibadan, 1973), IAEA, Vienna (1975), p. 105-123.

- 1976. Further investigations on the genetic control of seed protein production in Pisum mutants. In Evaluation of seed protein alterations by mutation breeding. (Proc. Meet. Hahnenklee, 1975), IAEA. Vienna (1976) p. 157-177.

HOLT, N. W. \& SOSULSKI, F. W. 1979. Amino acid composition and protein quality of field peas. Can. J. Plant Sci. 59:653-660.

HOVINEN, S. \& KARJALAINEN, R. 1981. Improvement of protein productivity under marginal conditions in Finland. Pisum Newsletter (in press).

JERMYN, W.A. \& SLINKARD, E.A. 1977. Variability of protein percent and its relationship to seed yield and seed shape in peas. Legume Res. 1: 33-37.

KIVI, E. 1978. Viljelyvarmuus palkokasvien jalostustavoitteena. Kasvinvilj.tiet. Lait. Julk. 3: 1-8.

- 1979. Züchterische Aspekte der einheimischen Eiweissversorgungen im Norden. J. Scient. Agric. Soc. Finl. 51: 1-16.

MÜLLER, H.P. \& GOTTSCHALK, W. 1978. Gene-ecological investigations on the protein production of different Pisum genotypes. In Seed protein improvement by nuclear techniques. (Proc. Meet. Bader, 1977), IAEA, Vienna (1978), p. 301-314.

PANDEY, S. \& GRITTON, E.T. 1976. Observed and predicted response to selection for protein and yield in peas. Crop Sci. 16: 298-292.

PESOLA, V. 1955. Protein content of field pea seeds as a varietal character. Acta Agr. Fenn. 83: 125-132.

RABSON, R., BHATIA, C. \& MITRA, R. K. 1978. Crop productivity, grain protein and energy. In Seed protein improvement by nuclear techniques. (Proc. Meet. Bader, 1977), IAEA, Vienna (1978) p. 3 20.

SNOAD, B. 1980. The origin, performance and breeding of leafless peas. Adas Quart. Rev. 37:69-86.

SWIECICKI, W. K., KACZMAREK, Z. \& SURMA, M. 1980. Inheritance of protein in peas. II. Heritability of protein content in Ranger $\mathrm{x}$ Strål and Paloma $\times$ Strål crosses. Pisum Newsletter. 12 $68-69$.

VARIS, E. 1981. Palkokasvi - R bižobium symbioosin kehittäminen maataloudessa. Maatalous 2:26-28.

Ms received September 8, 1981. 


\section{Herneen valkuaispitoisuuden vaihtelusta.}

\section{Reijo Karjalainen}

Kasvinjalostustieteen laitos, Helsingin yliopisto, 00710 Helsinki 71

\section{Simo Hovinen}

Hankeijan kasvinjalostuslaitos, 04300 Hyryla.

Herneen valkuaispitoisuuden vaihtelua tutkittiin Hankkijan kasvinjalostuslaitoksen Anttilan ja Nikkilän lajikekokeista vuosina 1975-1976 ja 1978-1980. Aineistosta tutkittiin lajikkeiden ja vuosien välistã vaihtelua. Regressioanalyysillä selvitettiin ilmastotekijöiden vaikutusta proteiinipitoisuuteen. Korrelaatioanalyysillä selvitettiin valkuaispitoisuuden korreloitumista tärkeimpiin viljelyominaisuuksiin.

Hernelajikkeiden välillã havaittiin valkuaispitoisuudessa tilastollisesti merkitseviä eroja. Vuosien välistä vaihtelua kuvattiin viiden lajikkeen variaatiokertoimilla. Proteiinipitoisuuden variaatiokerroin vaihteli $4.47-$ 9.12 ja valkuaissadon 41.62-53.11. Valkuaissadon suuri vaihtelu selittyi lähes täysin suuren siemensadon variaation perusteella. Kasvukaudenaikainen korkea lämpötila havaittiin tärkeimmäksi ilmastotekijäksi, joka lisãsi valkuaispitoisuutta.

Proteiinipitoisuus kytkeytyi pãäasiassa negatiivisesti siemensatoon, mutta korrelaatio oli heikko. Valkuaispitoisuus korreloi siemenen painoon negatiivisesti molemmilla koepaikoilla ja kaikkina vuosina. Proteiinipitoisuuden havaittiin lisääntyvän kasvuajan pidentyessä.

Tutkimuksesta ilmeni, että Suomen kasvuoloissa ympäristöolot säätelevät voimakkaasti sekä herneen valkuaispitoisuutta ettã proteiinisatoa. Valkuaisjalostuksessa näyttää olevan erittäin vaikeata yhdistäã korkea valkuaispitoisuus aikaiseen herneeseen. Aikaiset lajikkeet osoittautuivat kuitenkin varmimmiksi korkean valkuaissadon tuottajiksi, koska proteiinisato nãyttää selittyvän lähes täysin siemensadon tuoton perusteella. Proteiinituoton jalostuksessa on näin ollen tehokkaampaa pyrkiä parantamaan herneen siemensatoa ja sadontuoton varmuutta kuin proteiinipitoisuutta. 